Original

\title{
A Retrospective Study of 350 Dogs Suspected of Having Scabies (1988-1998)
}

\author{
疥癬が疑われた 350 例の犬に関する後向き研究（1988-1998）
}

\author{
Danny W. Scott*, William H. Miller, Jr. \\ Department of Clinical Sciences, College of Veterinary Medicine, Cornell University
}

Received July 7, 2012 and accepted December 28, 2012

\begin{abstract}
A retrospective study was conducted on 350 dogs suspected of having scabies, and 1,345 dogs with various dermatoses affecting the pinnae wherein the pinnal-pedal reflex was negative. Skin scrapings were positive in $29 \%$ of the dogs that responded to miticidal therapy. The pinnal-pedal reflex was positive in $78.4 \%$ of the dogs with confirmed (mites found in skin scrapings) and presumed (skin scrapings negative, but dog cured with miticidal therapy) scabies, and all of these had lesions on the pinnal margins. In contrast, only 1 to $12 \%$ of the dogs with other pinnal diseases had a positive pinnal-pedal reflex. Eighty-three percent of the dogs suspected of having scabies, but with negative skin scrapings, were cured with miticidal therapy. Dogs suspected of having scabies but not responding to miticidal therapy most commonly had atopic dermatitis or food allergy. Scabies accounted for $3.8 \%$ of the canine dermatology cases, and no age, breed, or sex predilections were observed.
\end{abstract}

Key words: dog, skin, scabies

要 約：疥癬が疑われた犬 350 例と, 耳介に皮膚疾患が認められたものの耳介一後肢反射が陰性で あった 1,345 例の犬に関する後向き研究を行った。駆虫薬の投与後に症状が改善した犬の $29 \%$ ば, 皮膚掻爪巴物鏡検により寄生虫が確認された。疥痒が確定された（皮膚掻爬物鏡検でダ二が検出され た）犬，ならびに疥癬が疑われた（皮膚掻爬物鏡検は陰性であったが駆虫薬の投与後に症状が改善 した）犬の $78.4 \%$ では耳介一後肢反射が陽性であり，またこれらの犬の全てで耳輪に皮膚症状が認 められた。これに対し, 疥痒とは異なる耳介の皮膚疾患を有する犬のうち, 耳介一後肢反射が陽性 であった症例はわずか 1 〜 $12 \%$ であった。疥瘉が疑われたものの皮膚掻爬物鏡検では陰性であっ た犬の $83 \%$ で，駆虫薬の投与後に症状が改善した。疥癬が疑われたものの駆虫薬により症状が改 善しなかった犬の多くが, アトピー性皮膚炎または食物アレルギーを有していた。疥揱は皮膚疾患 を主訴として来院した犬症例の $3.8 \%$ を占め, 年齢, 品種, 性別による差は認められなかった。 キーワード：犬, 皮膚, 疥癬

(Jpn J Vet Dermatol 2013, 19 (1): 3-9)

\section{Introduction}

Canine scabies (sarcoptic mange) is a contagious and zoonotic ectoparasitic skin disease caused by

* Correspondence to: Danny W. Scott (Department of Clinical Sciences, College of Veterinary Medicine, Cornell University), Ithaca, New York 14853-6401, USA

FAX+1-607-253-3534E-mail: shb3@cornell.edu infestation with the burrowing mite, Sarcoptes scabiei var canis, and characterized by intense nonseasonal pruritus and a typical distribution of papulocrustous lesions $1,6,9,11,17,18,23,24,32,34)$. The disease has been reported to be "common" 24$)$ or to account for $5 \%$ of the canine dermatology cases at a university clinic ${ }^{6)}$. No age, sex, or breed predilections have been reported.

Erythematous macules and crusted papules are most 
commonly seen in a more-or-less symmetrical pattern affecting the pinnae, face, ventrum, (especially the axillary and inguinal areas), elbows, hocks, legs, and feet. Thick, yellowish-gray-to-honey-colored crusts accumulate on the margins of the pinnae, elbows, and hocks. The dorsum is usually spared. Scabies is one of the most pruritic canine skin diseases, and affected dogs frequently continue to scratch in the examination room. Pruritus is often exacerbated by heat ${ }^{18,23,34)}$. The major differential diagnoses for canine scabies are atopic dermatitis, food allergy, contact dermatitis, Malassezia dermatitis, and adverse cutaneous drug reaction ${ }^{1,9,23,32 \text {. }}$.

The diagnosis of canine scabies is strongly suggested by the historical and clinical findings ${ }^{1,6,9,17,24,32,34)}$. The pruritus of canine scabies is often poorly-responsive to systemic glucocorticoid therapy (e.g., $1.1 \mathrm{mg}$ / $\mathrm{kg}$ prednisolone or prednisone given orally every 24 hours $)^{1,6,9,17,24,32,34)}$. A positive pinnal-pedal reflexprobably first described by Smith and Claypoole in $1967^{38)}$ - has been reported to be strongly suggestive of scabies, although the methodologies for performing this examination vary greatly, ${ }^{1,6,9,17,24,26,32,34,38)}$. In one large study, a positive pinnal-pedal reflex had a specificity of $93.8 \%$ and a sensitivity of $81.8 \%$ for a diagnosis of canine scabies ${ }^{26)}$.

The definitive diagnosis of canine scabies requires demonstrating mites and/or mite eggs in skin scrapings ${ }^{1,6,9,17,24,32,34)}$. However, skin scrapings are reported to be negative in 30 to $80 \%$ of the dogs with scabies $^{1,6,9,11,17,24,26,32,34)}$. It has also been reported that mites and/or mite eggs can occasionally be found in fecal flotations from dogs with scabies ${ }^{1,34}$. In 2 studies, mites and/or mite eggs were found in $3 / 11(27 \%)^{4)}$ and $5 / 53(10 \%)^{33)}$ dogs with scabies. Because mites and/or mite eggs are so difficult to demonstrate on dogs with scabies, skin scrapings are never used to exclude the diagnosis $^{1,6,9,11,12,16,17,24,32,34)}$. Hence, a therapeutic trial with reliable acaricidal products must be performed whenever canine scabies is suspected.

Our purpose is to report the results of a retrospective study on 350 dogs suspected of having scabies. In addition, we performed a retrospective study on dogs with pinnal dermatoses wherein the pinnal-pedal reflex was negative.

\section{Materials and Methods}

A retrospective study was conducted on 350 dogs with confirmed or suspected scabies seen by the Dermatology Service of the Cornell University Hospital for Animals (CUHA) from 1988 through 1998. Inclusion criteria included the following:

1. A more-or-less symmetrical macular-to-crusted papular dermatitis affecting the pinnae, face, ventrum, and limbs in various combinations.

2. Severe pruritus in the affected areas.

3. Incomplete response to antipruritic doses of systemic glucocorticoids.

Medical records were reviewed for the following information:

1. Signalment (breed, age, sex).

2. Dermatological findings.

3. Results of pinnal-pedal reflex.

4. Results of skin scrapings.

5. Therapeutic protocols and results.

6. Follow-up period.

Breed, age, and sex data for the dogs with confirmed and presumed scabies were compared with those for the general CUHA dog population for the same time period using the relative risk (RR) calculation.

$$
\mathrm{RR}=\frac{\text { data for scabies dogs }}{\text { data for CUHA dogs }}
$$

An RR of 2.0 or greater was considered significant. Dogs were treated with one of the following protocols according to the owner's wishes and in consideration of the breed (no ivermectin for susceptible breeds: collie, Shetland sheepdog, border collie, and old English Sheepdog):

1. Two percent lime sulfur dips, once weekly, with a final dip administered after clinical signs had resolved. All medium- and long-haired dogs were clipped. All dogs first received a detergent or antiseborrheic shampoo to remove crust, scale, and wax. The lime sulfur dip was applied to the entire body surface and allowed to dry. Swimming and bathing between dips was discouraged.

2. Ivermectin, $0.3 \mathrm{mg} / \mathrm{kg}$ by mouth, once weekly, with a final dose given after clinical resolution.

3. Milbemycin, $2.0 \mathrm{mg} / \mathrm{kg}$ by mouth, once weekly, with a final dose administered after clinical resolution.

4. Other treatments were not given.

The records reviewed identified 3 groups of dogs:

Group 1 (confirmed scabies): 90 dogs with typical historical and clinical findings, and positive skin scrapings.

Group 2 (presumed scabies): 220 dogs that had 


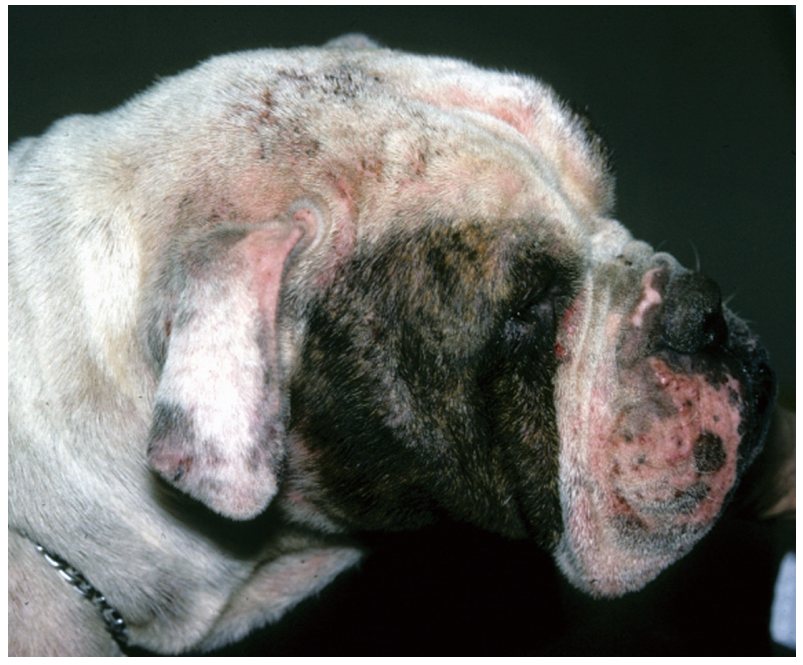

Fig. 1. Canine scabies (dog affected for 6 months). Erythema, papules, crusts, and traumatic alopecia on face and pinna.

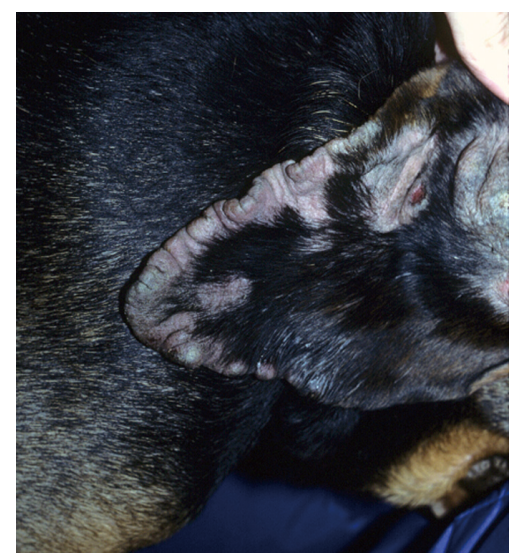

Fig. 2. Canine scabies (dog affected for over 1 year). Margin of pinnae is alopecic, crusted, erythematous, and lichenified.

typical historical and clinical findings and negative skin scrapings, and were cured with miticidal therapy.

Group 3 (not scabies): 40 dogs that had typical historical and clinical findings, negative skin scrapings, and no response to 6 to 8 weeks of miticidal therapy. These dogs had no known contact with possible asymptomatic carrier dogs during miticidal treatment.

These 3 groups were analyzed separately.

A retrospective study was also conducted (during the same time period) on another 1,345 dogs that presented with pinnal dermatoses for which the pinnal-pedal reflex was negative.

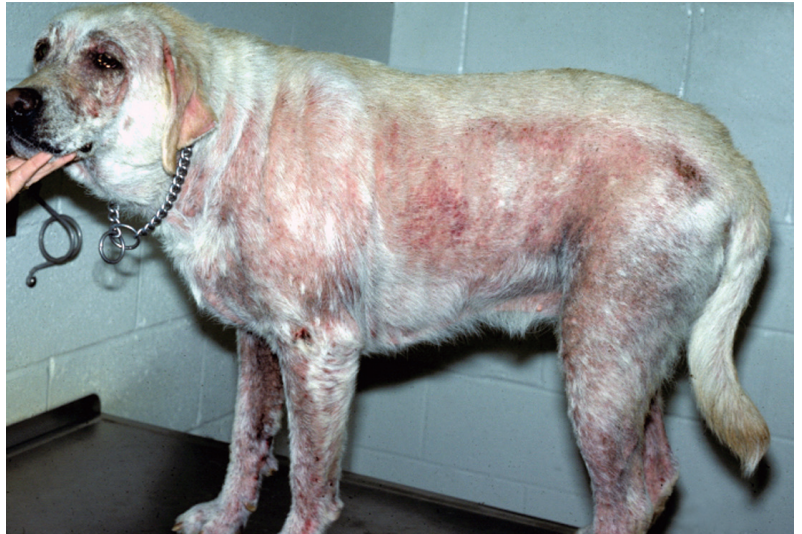

Fig. 3. Canine scabies (dog affected for 4 years). Note involvement of face, pinnae, ventrolateral trunk, and legs, but sparing of dorsum.

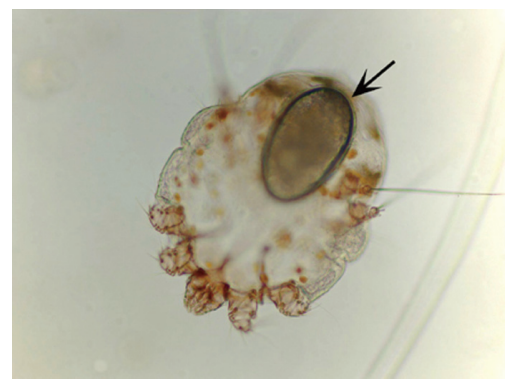

Fig. 4. Skin scraping in mineral oil from a dog with scabies. A gravid (note egg at arrow) adult Sarcoptes scabiei var canis is seen, 200X.

\section{Results}

All 350 dogs were suspected of having scabies based on historical and clinical findings (Figs. 1, 2, and 3). All dogs had been checked for intestinal parasites and heartworm infestation in the past and had been on various preventives. The margins of the pinnae were diseased in 283/350 dogs (80.9\%): 63/90 (70\%) group 1 dogs, 180/220 (81.8\%) group 2 dogs, and 40/40 (100\%) group 3 dogs. All dogs with pinnal margin lesions exhibited a positive pinnal-pedal reflex when a diseased area of the pinnal margin was vigorously rubbed between the thumb and forefinger. Dogs without pinnal lesions (67/350 dogs; 19.1\%) did not have a positive pinnal-pedal reflex: 27/90 (30\%) group 1 dogs and 40/220 (18.2\%) group 2 dogs.

Skin scrapings were performed on 3 to 5 approximately $2.5 \mathrm{~cm}^{2}$ areas of crusted or papular skin in all of the dogs. Skin scrapings were positive in 90/310 (29\%) dogs (Fig. 4) with confirmed and 
presumed scabies (groups 1 and 2). All skin scrapings were negative for other ectoparasites (e.g. Cheyletiella, Pelodera).

Dogs with confirmed and presumed scabies (groups 1 and 2) accounted for 310/8,207 (3.8\%) of the canine dermatology cases and $310 / 37,775(0.8 \%)$ of all dogs examined at the CUHA over an 11-year period. Scabietic dogs ranged from 2 months to 14 years of age, with no age predilections demonstrated. Males and females accounted for 163 (52.6\%) and 147 (47.4\%), respectively, of the cases, revealing no sex predilections. Sixty-two different breeds and mongrels were represented, with none being over-represented.

Dogs with confirmed and presumed scabies (groups 1 and 2) were treated and cured with ivermectin (159 cases), lime sulfur (81 cases), or milbemycin (51 cases). Length of therapy varied from 4 to 8 weeks. No side effects were reported. Patients lost to follow-up included 4 dogs (4.4\%) from group 1 and 19 dogs (8.7\%) from group 2.

Post-cure follow-up information ranging from 1 to 7 years was available for 37/86 (43\%) group 1 dogs. Only 1 dog was known to have developed scabies a second time. Post-cure follow-up information ranging from 1 to 9 years was available for 103/201 (51.2\%) group 2 dogs. Only 2 of these dogs were known to have contracted scabies a second time.

Group 3 (not scabies) dogs had the following final diagnoses:

1. Atopic dermatitis: 27 dogs.

2. Food allergy: 6 dogs.

3. Atopic dermatitis and food allergy: 2 dogs.

4. Presumed allergic dermatitis: 2 dogs. These dogs had the classic historical and physical findings of allergic skin disease: symmetrical and initial lesionless pruritus. These dogs all responded to antipruritic doses of systemic glucocorticoids and were clinically indistinguishable from dogs with atopic dermatitis or food allergy. Owners did not allow diagnostic testing (novel diet trial, serological, or intradermal testing). Hence, these dogs probably had either atopic dermatitis, food allergy, or both of these.

5. Malassezia dermatitis: $1 \mathrm{dog}$.

6. Epitheliotropic lymphoma: $1 \mathrm{dog}$.

All group 3 dogs had pinnal lesions and positive pinnal-pedal reflexes. These dogs ranged from 5 months to 12 years of age (no age predilection), included 18 (45\%) males and 22 (50\%) females (no sex predilection), and no breed was over-represented. One dog was lost to follow-up.

Wherein follow-up information was available, $201 / 241(83 \%)$ dogs that were suspected of having scabies - but had negative skin scrapings - were cured with miticidal therapy.

During the same time period (1988-1998), 1,345 dogs with pinnal dermatoses and negative pinnal-pedal reflexes were evaluated on the Dermatology Service. Diagnoses for these were as follows:

1. Atopic dermatitis: 418 dogs.

2. Presumed allergic dermatitis: 195 dogs.

3. Primary seborrhea: 173 dogs.

4. Generalized demodicosis: 125 dogs.

5. Pemphigus foliaceus: 59 dogs.

6. Malassezia dermatitis: $50 \mathrm{dogs}$.

7. Food allergy: 45 dogs.

8. Vasculitis: 26 dogs.

9. Sebaceous adenitis: 26 dogs.

10. Adverse cutaneous drug reaction: 23 dogs.

11. Fly-bite dermatitis: 22 dogs.

12. Atopic dermatitis and food allergy: 21 dogs.

13. Zinc-responsive dermatitis: 19 dogs.

14. Familial dermatomyositis: 18 dogs.

15. Epitheliotropic lymphoma: 14 dogs.

16. Dermatophytosis: 13 dogs.

17. Ichthyosis: 11 dogs.

18. Juvenile cellulitis: 11 dogs.

19. Systemic lupus erythematosus: 9 dogs.

20. Sterile pyogranuloma syndrome: 9 dogs.

21. Ear margin dermatosis: 9 dogs.

22. Necrolytic migratory erythema: 9 dogs.

23. Aural hematoma: 7 dogs.

24. Erythema multiforme: 6 dogs.

25. Otodectic mange: 6 dogs.

26. Sterile eosinophilic pustulosis: 5 dogs.

27. Epidermal dysplasia: 4 dogs.

28. Eosinophilic folliculitis and furunculosis: 3 dogs.

29. Cheyletiellosis: 3 dogs.

30. Cutaneous lupus erythematosus: 3 dogs.

31. Sterile eosinophilic folliculitis of the pinna: 3 dogs.

All of the above diagnoses were confirmed by standard history, clinical, laboratory, and therapeutic criteria $^{34)}$. When we compare group 3 dogs (positive pinnal-pedal reflex but not scabies) with dogs with the same diagnoses but negative pinnal-pedal reflex, we find the following prevalences of positive pinnal-pedal reflex 
in the respective dermatoses:

1. Atopic dermatitis: $27 / 445$ dogs (6\%).

2. Presumed allergic dermatitis: $2 / 197$ dogs (1\%).

3. Malassezia dermatitis: $1 / 51$ dogs $(2 \%)$.

4. Food allergy: 6/51 dogs (12\%).

5. Atopic dermatitis and food allergy: $2 / 23$ dogs (8.6\%).

6. Epitheliotropic lymphoma: $1 / 15$ dogs (6.7\%).

These prevalences ( 1 to $12 \%$ ) of positive pinnalpedal reflex are clearly much lower than that $(100 \%)$ in the group 1 (confirmed scabies) and group 2 (presumed scabies) dogs that had pinnal lesions.

\section{Discussion}

Scabies is common in our area, accounting for 3.8\% of our canine dermatology cases. These findings are in agreement with previous anecdotal reports ${ }^{6,24)}$. We found no breed, sex, or age predilections. This is also consistent with previous literature.

We strongly agree that the typical historical and clinical features of canine scabies are very suggestive of the diagnosis $1,6,9,17,24,32,34)$. In our study, $260 \mathrm{dogs}$ were suspected to have scabies, but had negative skin scrapings. Follow-up information was available for 241 of these dogs, and $83 \%$ were cured with miticidal therapy.

We also agree that skin scrapings are positive in the minority $-29 \%$ - of the dogs with scabies. It is impossible to compare our results and those of other studies, as the methodologies were so different. For instance, recommendations for performing skin scrapings vary from: perform "multiple" scrapings ${ }^{34)}$; perform 6 to 7 scrapings over a "large" area"; scrape 8 to 10 different sites $^{11)}$; perform 8 to 20 scrapings $^{32)}$; perform 3 to 14 scrapings on a 25 to $100 \mathrm{~cm}^{2}$ area of clipped skin ${ }^{25)}$; to scrape a 14 to $15 \mathrm{~cm}^{2}$ area of clipped skin ${ }^{12,21)}$. In an unpublished study performed in 1974 ${ }^{33)}$, 25 skin scrapings/ dog were performed on 57 dogs with typical historical and clinical findings of scabies that were cured with lime sulfur dips. Mites and/or mite eggs were found in only 29/57 (51\%) dogs. Even when found, mites and/or mite eggs are often in very small numbers, e.g., 1 egg/ $\operatorname{dog}^{10)} ; 1$ adult and 4 eggs in 30 skin scrapings from $3 \operatorname{dogs}^{28)}$. We performed fewer skin scrapings (3 to $5 / \mathrm{dog}$ ) on a smaller surface area (approximately $2.5 \mathrm{~cm}^{2} /$ scraping) than recommended by many authors $11,12,21,26,32)$. However, our protocol is more representative of what is done in a busy veterinary practice in our area.
The pinnal-pedal reflex, as performed in our study and by others ${ }^{24,38)}$, was positive in $78.4 \%$ of the dogs with confirmed and presumed scabies in our study. All dogs with the positive pinnal-pedal reflex had lesions on the margins of their pinnae. The $21.6 \%$ of the dogs with confirmed and presumed scabies that did not have a positive pinnal-pedal reflex also did not have pinnal margin lesions. By contrast, 1,345 dogs with pinnal diseases associated with other conditions - especially atopic dermatitis, food allergy, or both of these - did not have a positive pinnal-pedal reflex. We agree that the positive pinnal-pedal reflex is very suggestive of the diagnosis of canine scabies ${ }^{1,17,26,32,34)}$.

Pelodera dermatitis and hookworm dermatitis are very rare in our area. Both conditions present with papulocrustous lesions and pruritus in glabrous, contact areas of skin. Lesions in our confirmed and presumed scabies dogs were not confined to glabrous skin. Pelodera and hookworm dermatitis arise from a filthy, contaminated environment. Our patients did not have contact with such environments. Pelodera nematodes are numerous in skin scrapings, but were not found in our patients. Hookworm larvae are not found in skin scrapings, and our patients had had negative fecal flotations and had been on preventive medicines.

Given that a definitive diagnosis (positive skin scrapings or fecal flotations) of canine scabies is achieved in a minority of cases, response to a reliable miticide is the only way to confirm a tentative diagnosis (presumed scabies) 1, 6, 9, 11, 12, 16, 17, 24, 32, 34). Products reported to be effective for the treatment of canine scabies include 2 to $3 \%$ lime sulfur dips ${ }^{1,6,9,16,17,24,32,34)}$, $0.09 \%$ phosmet dips $^{6,9,21)}, 4 \%$ malathion dips ${ }^{1,34)}, 250$ to 500 ppm amitraz dips $6,9,11,12,16,17,27,34,42)$, deltamethrin spray $^{36)}$, fipronil spray ${ }^{6,8,9,16,22,23,34)}$, ivermectin pour-on ${ }^{28)}$, moxidectin spot-on ${ }^{13-15)}$, amitraz spot-on ${ }^{14)}$, pyriprole spot-on $^{15)}$, selamectin spot-on ${ }^{9,16,24,29,34,35)}$, moxidectin orally or subcutaneously ${ }^{41)}$, doramectin subcutaneously ${ }^{19)}$, milbemycin orally ${ }^{5,9,10,16,24,34,37)}$, and ivermectin orally or subcutaneously 6 , 9, 16, 17, 20, 24, 30-32, 34). In our study, $83 \%$ of the dogs with presumed scabies were cured with miticidal therapy. Ivermectin, lime sulfur, and milbemycin were all highly effective in our

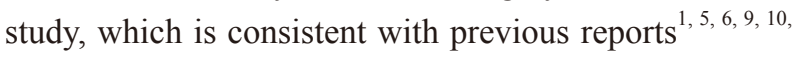
$16,17,20,24,25,30-32,34,37)$. Although sulfur has been widely recommended for many years for the treatment of canine scabies $^{1,6,9,16,17,18,23,24,32,34)}$, ours is the first study to document its efficacy in a large number (81) of dogs. 
Any topical product that must be applied to and left on the entire body surface, and must be preceded by clipping the hair coat of medium- and long-haired dogs, will be more labor-intensive and possibly undesirable for some owners.

Because our study involved cases seen in 1988 through 1998, many of the newer miticides (moxidectin, doramectin, selamectin, fipronil, pyriprole, amitraz spot-on) were not available. We did have one skin scrape-positive case that did not respond to monthly selamectin, but was cured with ivermectin. Other authors have cited anecdotal failures with monthly selamectin, and recommend it be administered every 2 weeks ${ }^{9,16,29)}$. This situation is not unique to selamectin. Some authors also cite the need to apply amitraz spot-on ${ }^{14)}$ and fipronil ${ }^{8,9,16,22,24)}$ more often than label recommendations for more consistent benefit. Ivermectin-resistant scabies has rarely been reported in $\operatorname{dogs}^{40)}$ and humans ${ }^{7}$. We did not use topical organophosphates (dichlorvos, phosmet, ronnel) because $\mathrm{we}^{33,34)}$ and others ${ }^{6,9,17)}$ had found them unreliable and potentially toxic.

Experimental infestations and reinfestations of dogs with S. scabiei var canis mites have demonstrated the induction of both cell-mediated and humoral immunity, protective immunity, and even spontaneous resolution of disease $^{2,3,39)}$. To our knowledge, spontaneous resolution of canine scabies as seen by veterinary practitioners has not been reported.

Recurrent canine scabies has not been addressed in the literature. We did observe 3 dogs that developed scabies a second time during our study.

The duration of therapy for canine scabies requires some discussion. The life cycle of S. scabiei var canis is typically 17 to 21 days $^{1,9,11,17,32,34)}$. However, it is well known that pruritus and dermatitis can persist after the inability to demonstrate mites by skin scrapings ${ }^{1,11-15,17,22,34,35)}$. This prolonged pruritus and dermatitis is presumed to be due to the ongoing allergic reaction to mite antigen(s). Hence, treatment is typically continued until pruritus and all active skin lesions have disappeared (4 to 12 weeks) ${ }^{1,5,6,9,17,22,32,37,41)}$.

Our study is the first to address dogs that were presumed to have scabies but failed to respond to therapy. Of 241 dogs with negative skin scrapings from our study, 40 (17\%) failed to respond to miticidal treatment. The most common diagnoses in this group of dogs were atopic dermatitis and food allergy.

\section{References}

1) Anderson, R.K. 1979. Canine scabies. Compend. Cont. Educ. 1: 687-694.

2) Arlian, L.G., Morgan, M.S., Rapp, C.M. and Vyszenski-Moher, D.L. 1996. The development of protective immunity in canine scabies. Vet. Parasitol. 62: 133-142.

3) Arlian, L.G. and Morgan, M.S. 2000. Serum antibody to Sarcoptes scabiei and house dust mite prior to and during infestation with S. scabiei. Vet. Parasitol. 90: 315-316.

4) Baker, B.B. and Stannard, A.A. 1974. A look at canine scabies. J. Am. Anim. Hosp. Assoc. 10: 513-515.

5) Bergvall, K. 1998. Clinical efficacy of milbemycin oxime in the treatment of canine scabies: a study of 56 cases. Vet. Dermatol. 9: 231-233.

6) Bond, R. 1998. Diagnosis and treatment of canine scabies. In Pract. 20: 308-315.

7) Currie, B.J., Harumal, P., McKinnon, M., and Walton, S.F. 2004. First documentation of in vivo and in vitro ivermectin resistance in Sarcoptes scabiei. Clin. Infect. Dis. 39: 8-12.

8) Curtis, C.F. 1996. use of 0.25 percent fipronil spray to treat sarcoptic mange in a litter of five-week-old puppies. Vet. Rec. 139: 43-44.

9) Curtis, C. and Paradis, M. 2003. Sarcoptic mange, cheyletiellosis and trombiculosis. pp. 146-152. In: BSAVA Manual of Small Animal Dermatology, 2nd ed. (Foster, A.P. and Foil, C.S. eds.), British Small Animal Veterinary Association, Gloucester.

10) de Jaham, C. and Henry, C.J. 1995. Treatment of sarcoptic mange using milbemycin oxime. Can. Vet. J. 36: 42-43.

11) Folz, S.D. 1984. Canine scabies (Sarcoptes scabiei infestation). Compend. Cont. Educ. 6: 176-180.

12) Folz, S.D., Kratzer, D.D., Kakuk, T.J. and Rector, D.L. 1984. Evaluation of a sponge-on therapy for canine scabies. J. Vet. Pharmacol. Therap. 7: 29-34.

13) Fourie, L.J., Heine, J. and Horak, I.G. 2006. The efficacy of an imidacloprid/moxidectin combination against naturally acquired Sarcoptes scabiei infestations in dogs. Aust. Vet. J. 84: 17-21.

14) Fourie, L.J., Kolc, D.J., du Plessis, A. and Rugg, D. 2007. Efficacy of a novel formulation of metaflumizone plus amitraz for the treatment of sarcoptic mange in dogs. Vet. Parasitol. 150: 275281. 
15) Fourie, J.J., Horak, I.G. and de la Puente Redondo, V. 2010. Efficacy of a spot-on formulation of pyriprole on dogs infested with Sarcoptes scabiei. Vet. Rec. 167: 442-445.

16) Ghubash, R. 2006. Parasitic miticidal therapy. Clin. Tech. Small Anim. Pract. 21: 134-144.

17) Griffin, C.E., Kwochka, K.W. and MacDonald, J.M. 1993. pp. 85-89. In: Current Veterinary Dermatology-The Science and Art of Therapy, Mosby Year Book, St. Louis.

18) Hutyra, F. and Marek, J. 1926. pp. 748-751. In: Special Pathology and Therapeutics of the Diseases of Domestic Animals, 3rd ed., Alex and Eger, Chicago.

19) Jagannath, M.S. and Yathiraj, S. 1999. Clinical evaluation of doramectin in the treatment of ectoparasites of canines. Indian Vet. J. 76: 333-336.

20) Khosla, R., Verma, H.K., Chaudhary, R.K. and Dwived, P.N. 1991. A mixed infection of scabies and pyodermatitis in dogs: a clinico-therapeutic approach. Indian Vet. J. 68: 569-570.

21) Knapp, F.W. 1978. Paramite ${ }^{\circledR}$ dip for control of sarcoptic mange on dogs. Vet. Med. Small Anim. Clin. 73: 1161-1163.

22) Koutinas, A.F., Saridomichelakis, M.N., Soubasis, N., Bornstein, S. and Koutinas, C.K. 2001. Treatment of canine sarcoptic mange with fipronil spray: a field trial. Aust. Vet. Practit. 31: 115-119.

23) Král, F. and Schwartzman, R.M. 1964. pp. 362365. In: Veterinary and Comparative Dermatology, J.B. Lippincott, Philadelphia.

24) Medleau, L. and Hnilica, K.A. 2001. pp. 71-73. In: Small Animal Dermatology. A Color Atlas and Therapeutic Guide, W.B. Saunders, Philadelphia.

25) Miller, W.H. Jr., de Jaham, C., Scott, D.W., Cayatte, S.M., Bagladi, M.S. and Buerger, R.G. 1996. Treatment of canine scabies with milbemycin oxime. Can. Vet. J. 37: 219-221.

26) Mueller, R.S., Bettenay, S.V. and Shipstone, M. 2001. Value of the pinnal-pedal reflex in the diagnosis of canine scabies. Vet. Rec. 148: 621-623.

27) Muhammad, G., Khan, M.Z., Umar, A., Javed, R.S. and Khan, S.A. 1985. Amitraz (Mitac $\AA$ - Boots) against canine scabies - clinical trials. Pakistan Vet. J. 5: 48-50.

28) Paradis, M., de Jaham, C. and Pagé, N. 1997. Topical (pour-on) ivermectin in the treatment of canine scabies. Can. Vet. J. 38: 379-382.
29) Pin, D., Bensignor, E., Carlotti, D.N. and Cardiergues, M.C. 2006. Localized sarcoptic mange in dogs: a retrospective study of 10 cases. $J$. Small Anim. Pract. 47: 611-614.

30) Rai, M.T. and Yathiraj, S. 1988. Clinical evaluation of ivermectin for treatment of scabies in canines. Indian Vet. J. 65: 626-628.

31) Scheidt, V.J., Medleau, L., Seward, R.L. and Schwartzman, R.M. 1984. An evaluation of ivermectin in the treatment of sarcoptic mange in dogs. Am. J. Vet. Res. 45: 1201-1202.

32) Schmeitzel, L.P. 1988. Cheyletiellosis and scabies. Vet. Clin. N. Am. Small Anim Pract. 18: 1069-1076.

33) Scott, D.W. 1974. Unpublished data. Cornell University, College of Veterinary Medicine, Ithaca.

34) Scott, D.W., Miller, W.H. Jr. and Griffin, C.E. 2001. pp. 475-483. In: Muller \& Kirk's Small Animal Dermatology, 6th ed., W.B. Saunders, Philadelphia.

35) Shanks, D.J., McTier, T.C., Behan, S., Pengo, G., Genchi, C., Bowman, D.D., Holbert, M.S., Smith, D.G., Jerrigan, A.D. and Rowan, T.G. 2000. The efficacy of selamectin in the treatment of naturally acquired infestations of Sarcoptes scabiei on dogs. Vet. Parasitol. 91: 269-281.

36) Sharma, M.C., Swarup, D. and Lal, S.B. 1991. Therapeutic efficacy of Butox ${ }^{\circledR}$ (deltamethrin) against mange in dogs. Indian Vet. J. 68: 80-83.

37) Shipstone, M., Mueller, R. and Bettenay, S. 1997. Milbemycin oxime as a treatment for canine scabies. Aust Vet. Practit. 27: 170-173.

38) Smith, E.B. and Claypoole, R.F. 1967. Canine scabies in dogs and in humans. J. Am. Med. Assoc. 199: 95-100.

39) Stemmer, B.L., Arlian, L.G., Morgan, M.S., rapp, C.M. and Moore, P.F. 1996. Characterization and antigen presenting cells and T-cells in progressing scabietic skin lesions. Vet. Parasitol. 67: 247-258.

40) Terada, Y., Murayama, N., Ikemura, H., Morita, T. and Nagata, M. 2010. Sarcoptes scabiei var. canis refractory to ivermectin treatment in two dogs. Vet. Dermatol. 21: 608-612.

41) Wagner, R. and Wendelberger, U. 2000. Field efficacy of moxidectin in dogs and rabbits naturally infested with Sarcoptes spp., Demodex spp. and Psoroptes spp. mites. Vet. Parasitol. 93: 149-158.

42) Yathiraj, S., Rao, P.M., Reddy, N.R.J. and Rai, M.T. 1990. Treatment of scabies in canines with amitraz. Indian Vet. J. 67: 867-868. 